\title{
Business Strategy for Atlantic City Hotel Facing Covid-19 Pandemic
}

\author{
Gilang Permana Rachman ${ }^{1}$, Anh-Dung Do ${ }^{2}$ \\ ${ }^{1,2}$ School of Business and Management of Institut Teknologi Bandung, Jakarta Indonesia
}

\begin{abstract}
As the supporting industry of the economic sector, the tourism industry has been impacted deeply by the Covid-19 pandemic. The social activities restrictions in the early pandemic, from March to June 2020, became the biggest disaster for the tourism industry, especially the hospitality industry. Atlantic City Hotel is one of the hotels that survived this pandemic even though some financial restrictions have done caused by the decreasing income impact of the low occupancy rate. In this research, two kinds of data are used to obtain the information: primary and secondary data, then analysed using the PESTEL framework, Porter's Five Forces framework, and Perceptual Mapping framework to understand the external condition.

On the other hand, the Resources-based view framework, Value Chain Analysis, and reviewing existing business model canvas are used for internal conditions. Using some methods such as SWOT analysis, TOWS matrix, Porter's Generic Strategy, Diamond Strategy, and adjusted Business Model Canvas will consequence business solution for Atlantic City Hotel facing the Covid-19 pandemic such as Hotels can pursue differentiating and cost leadership strategies at the same time. In addition, hotels can also make improvements in technology and its use for innovation activities. Technology is also used as a marketing tool, covering the lack of hotel facilities, and preventing the spread of the COVID-19 virus.
\end{abstract}

KEYWORDS: Atlantic City Hotel, Bandung, Business Strategy, Covid-19, Hospitality Industry, Pandemic.

\section{INTRODUCTION}

Atlantic City Hotel has been doing business very well. The company continues to develop its business with various efforts. The company projects that each year will maintain a profit of around IDR 6 billion and the average occupancy rate is also targeted at around $70 \%$ every year. This rapid development had to stop because of the covid-19 pandemic. Starting in March 2020, when the Covid-19 virus was declared to have spread in Indonesia, the Indonesian government at this moment stated that it was imposing largescale social restrictions (PSBB). This restriction reduces the arrival of foreign tourists. If domestic tourists look at 300 million visits per year until December, there is a decrease of $90 \%$ or decreased 270 million trips. With this policy, Atlantic City Hotel is also forced to reduce the expenses of its operations during the pandemic era.

Atlantic City Hotel projects that for 2021, conditions can return to normal where revenue is around IDR 13.5 billion, profit is IDR 6 billion, and room occupancy rates are at $70 \%$. This optimism grew along with the start of a mass vaccination program for workers in the public service sector. Therefore, the strategy must be prepared carefully considering that in 2021 the government is also intensely promoting mass vaccination. With this program, there is new hope to revive the business wheels that are slowing down.

\section{LITERATURE REVIEW}

SWOT (Strengths, Weaknesses, Opportunities, and Threats) Analysis is one of the techniques used to appraise a firm to design a new strategy. The strengths, weaknesses, opportunities, and threats (SWOT) analysis assists a company in being aware of all the aspects involved in making strategic decisions. Internal environments contain both strengths and weaknesses, over which organizations have some influence. The external environment includes opportunities and threats that occur outside of the firm and in the wider market. Organizations may seize opportunities and defend against challenges, but they seldom evolve. (Hattangadi, Vidya. 2021).

Heinz Weihrich first introduced TOWS Matrix in his publications - A Tool for Situational Analysis in 1982. TOWS matrix is the extension of SWOT Analysis that combines the external and internal analysis. The TOWS analysis goes beyond the SWOT analysis paradigm, connecting strengths with opportunities and threats with weaknesses. We use the TOWS matrix to detect links between these parameters and then choose tactics based on them. We generate a chart in the TOWS matrix to compare internal (strengths and weaknesses) interacting with external characteristics (i.e., opportunities and threats) (Hattangadi, Vidya. 2021). 


\section{International Journal of Current Science Research and Review}

ISSN: 2581-8341

\section{Volume 05 Issue 02 February 2022}

DOI: 10.47191/ijesrr/V5-i2-04, Impact Factor: 5.825

Porter's Generic Strategy matrix highlights cost leadership, differentiation, and focus on the three basic choices for firms. According to this model, a firm can select how it wishes to compete depending on the match between the sort of competitive advantage it has and the market goal it is pursuing, as the important determinants of choice (Bordean et al., 2010). Porter's (1980) generic strategy model offers practitioners with an analytical approach for comprehending industries and rivals. Porter defines "practitioners" as "managers seeking to improve the performance of their businesses, advisors to managers, management teachers, security analysts, and other observers attempting to understand and forecast business success or failure, or government officials seeking to understand competition in order to formulate public policy." (Minarik. 2007).

Diamond Strategy. Donald Hambrick and James Fredrickson proposed diamond strategy in 2001 as a simple approach to look at how the pieces of an organization's strategy fit together. According to Hambrick and Fredrickson, a technique consists of five aspects that provide answers to real-world questions: (1) Arena - where will be active? (2) Vehicles - how will we get there? (3) Differentiators - how will we win in the marketplace? (4) Staging - what will be our speed and sequence of moves? (5) Economic logic - how will we obtain our returns? (Hambrick \& Fredrickson. 2001).

Business Model Canvas. Alex Osterwalder, a Swiss business theorist and entrepreneur, devised the canvas as part of his Ph.D. study. The Business Model Canvas was developed in the book Business Model Generation, which he co-authored with his graduate supervisor, Belgian computer scientist Yves Pigneur (Mansfield, T. 2019). A business model canvas is a strategic management tool used to outline how a company produces, transports, and collects value.

\section{METHODOLOGY}

Several data are needed to support the analysis of this research, such as primary and secondary data. For primary data, interviews and questionnaires are done to get some information. At the same time, the secondary data is obtained by observing the feedback from customers through travel applications, news, journal, Etc.

The researcher itself obtains primary data. The primary data will use qualitative as the method of the researcher's approach. The researcher interviewed 11 persons: General Manager of Atlantic City Hotel, competitor, West Java Tourism and Culture Department representative of Indonesian Hotel and Restaurant Association, marketing specialist, hospitality practitioner, public health practitioner, self-isolation customer, and some hotel customers. Besides, this study has done the survey questionnaire online using email and chat links, and it obtained the answered from 138 persons.

Besides, the researcher also needs secondary data to support the observation. Secondary data are collected from the customer feedback through travel applications, news, journal, Etc. The secondary data are also used to find competitors' data like price, facilities, and customer opinion.

Then, those data will be analyzed. The analysis result is sorted into external analysis that consists of PESTEL, Poster's Five Forces, and Perceptual Mapping and internal analysis that consists of VRIO and Existing Business Model Canvas. Next, the internal and external analysis will construct the SWOT, New Business Model Canvas, and Strategy Formulation.

\section{RESULT AND DISCUSSIONS}

Atlantic City Hotel has been doing business very well. The company continues to develop its business with various efforts. The company projects that each year the profit will be maintained around IDR 6 billion and the average occupancy rate is also targeted at around $70 \%$ every year.

According to the General Manager of Atlantic City Hotel, Mr. Dida, Atlantic's revenue for April - June 2020 was recorded at IDR 150 million with an average occupancy rate of around 15\% to 17\%. Atlantic City Hotel projects that for 2021, conditions can return to normal where revenue is around IDR 13.5 billion, profit is IDR 6 billion, and room occupancy rates are at 70\%. This optimism grew along with the start of a mass vaccination program for workers in the public service sector. Therefore, the strategy must be prepared carefully considering that in 2021 the government is also intensely promoting mass vaccination. With this program, there is new hope to revive the business wheels that are slowing down.

Besides, this pandemic made the customer segment change into a mystery market. It means the hotel does not know what kind of customer will come. They rely on travel e-commerce such as Traveloka, Tiket.com, Pegi-Pegi, and Agoda. In this situation, Atlantic City Hotel is still struggling to find the market. The mayor's regulations have also deteriorated for hotels. The Mayor of Bandung announced it forbids and shuts himself off from tourists. Mr. Dida believes that the Bandung Government should welcome tourists 


\section{International Journal of Current Science Research and Review}

ISSN: 2581-8341

\section{Volume 05 Issue 02 February 2022}

DOI: 10.47191/ijesrr/V5-i2-04, Impact Factor: 5.825

IJCSRR@ 2022

and guests from outside the area. The health officer gives guests who come health protocol education. Because the internal hotels in the city of Bandung are ready to enforce health protocols

The same condition also happens to another hotel, Sari Ater Hotel Kamboti. The occupancy rate fell around 20\% - 25\%. Hotel cost around IDR 375,000 - IDR 425,000. So, the revenue at around IDR 270 million monthly. The General Manager explained that the government has distributed tax refunds to hotels that obey taxes. However, this is not enough because, in the hospitality industry, the most important thing is market availability. Currently, rigid regulations have resulted in this industry not being able to run optimally. Restrictions on the number of rooms and activities carried out by the Bandung Government made occupancy and income unable to increase.

The Indonesia Hotel and Restaurant Association (PHRI) made a task force to propose a strategy \& recovery action post-covid-19 program for the government and hoteliers. PHRI becomes a bridge between the government and hoteliers, so every recommendation, input, and suggestion is conveyed by both parties. On another side, the West Java Tourism and Culture Department carries out strategies and mitigation for the hotel industry to face the COVID-19 pandemic, consisting of three stages, namely the emergency response stage (P1), P1 and recovery (P2) stages, and P2 and normalization stages. These three stages will be held from 2020 until 2024. However, the West Java Tourism and Culture Office does not deny that the rules for limiting capacity cannot be contested in the hospitality industry. What has been regulated by the covid-19 task force must be obeyed to avoid sanctions, so health protocols are indeed the primary key. The Ministry of Tourism has also provided hygiene, health, and safety guidelines for the hospitality sector. Then, the acceleration of vaccination for the tourism sector continues to be pursued. The tourism and health offices have recorded the number of vaccination participants. The tourism office also expects every hotel management to accelerate vaccination by actively coordinating with the nearest health center.

The marketing specialist argues that, in general, the condition of the hospitality industry is severe. With restrictions on people's activities, capacity restrictions, and travel conditions make it difficult for visitors to come to tourism cities, leading to reduced hotel revenue. She also believes that the revenue improvement efforts carried out by the hotel have not been maximized, but the effort is gradual. Most hotels are currently building customer awareness and providing education that their hotel is safe, and they are implementing strict health protocols. This objective awareness will eventually lead to revenue. Second, the hotel can use the marketing tools and programs to attract the customer; for example, the hotel can try e-mail marketing which contains vouchers or hotel security information during a pandemic and then send to hotel guests who have visited. Hotel guests who have visited this hotel should be given special treatment and make them remarketing audiences, not new guests.

This research also asked the suggestion of public health practitioners for the hoteliers:

(a) Food is not served in a buffet, delivered to each guest's room, served food in closed conditions,

(b) Provide hand sanitizer in each room and public space such as the lobby, entrance, or near the elevator,

(c) All waiters, receptionists, housekeeping, and all hotel employees wear masks and face shields,

(d) When checking in, the hotel continuously checks the guest's body temperature, keeps a distance from guests,

(e) Use plexiglass divider between receptionist and guest,

(f) Giving masks, face shields, or vitamins can be done as a promotional effort,

(g) Change the bed sheet two times a day,

(h) Periodically check the temperature of each guest who enters the hotel,

(i) Prepare health facilities if a guest is sick,

(j) Clean regularly banisters, elevator buttons, and other items that guests frequently access,

(k) Make sure guests keep their distance by putting a cross on the chair or prayer room floor,

(l) Placing reminders to wash hands and wear masks.

In this study, a research method was also carried out using questionnaires distributed online, either by e-mail blast or by sharing in chat groups. This questionnaire was conducted to find out basic information, customer preferences in choosing hotels during this pandemic, and to draw opinions for hotel development. Respondents who can fill in are respondents who have visited Bandung in the past year (during the pandemic) or are domiciled in Bandung. One hundred thirty-eight people from different backgrounds filled out this questionnaire. The summary of the questionnaire result will be presented in the following table. 


\section{International Journal of Current Science Research and Review}

ISSN: 2581-8341

Volume 05 Issue 02 February 2022

DOI: 10.47191/ijesrr/V5-i2-04, Impact Factor: 5.825

IJCSRR@ 2022

Table 1. The Questionnaire Questions and Answers

\begin{tabular}{|c|c|c|}
\hline No & Questions & Results \\
\hline 1 & What is your gender? & $\begin{array}{l}\mathbf{5 3 . 6 \%} \text { - Female } \\
46.4 \% \text { - Male }\end{array}$ \\
\hline 2 & How old are you? & $\begin{array}{l}\mathbf{2 0}-\mathbf{3 0} \text { years }=\mathbf{8 0 . 4 \%} \\
30-40 \text { years }=11.6 \% \\
\text { Others }=8 \%\end{array}$ \\
\hline 3 & Where do you live? & $\begin{array}{l}\text { Jabodetabek }=\mathbf{4 4 . 2 \%} \\
\text { West Java }=43.5 \% \\
\text { East Java }=2.9 \% \\
\text { Central Java }=2.2 \% \\
\text { Others }=7.2 \%\end{array}$ \\
\hline 4 & How often have you visited Bandung during this pandemic? & $\begin{array}{l}\text { Living in Bandung }=37 \% \\
\text { One time }=23.2 \% \\
\text { Two times }- \text { more }=\mathbf{3 9 . 8 \%}\end{array}$ \\
\hline 5 & What did you do during the visit? & $\begin{array}{l}\text { Most respondents answered: } \\
\text { Their residence, business, holiday, or family } \\
\text { events. }\end{array}$ \\
\hline 6 & $\begin{array}{l}\text { Did you stay/have you ever stayed at a hotel while in Bandung } \\
\text { during the pandemic? }\end{array}$ & $\begin{array}{l}\mathbf{5 5 . 1} \% \text { said yes } \\
44.9 \% \text { said no }\end{array}$ \\
\hline 7 & $\begin{array}{l}\text { What is your biggest consideration in choosing a place to stay when } \\
\text { in Bandung during the pandemic (can choose more than one)? }\end{array}$ & $\begin{array}{l}\text { Five things that many respondents consider } \\
\text { are: } \\
\text { 1. Price } \\
\text { 2. Facilities and services } \\
\text { 3. Cleanliness } \\
\text { 4. Locations } \\
\text { 5. Health Protocol }\end{array}$ \\
\hline 8 & Do you know about this CHSE certificate? & $52.9 \%$ didn't know \\
\hline 9 & $\begin{array}{l}\text { Did you know that some hotels in Bandung have been CHSE } \\
\text { certified? }\end{array}$ & $\begin{array}{l}\mathbf{7 1 \%} \text { didn't know some hotels in Bandung } \\
\text { have CHSE certificate }\end{array}$ \\
\hline 10 & $\begin{array}{l}\text { Does the hotel's CHSE certification make you feel safer to stay } \\
\text { during a pandemic? }\end{array}$ & $\begin{array}{l}\mathbf{8 1 . 2 \%} \text { feel safer with Hotel's CHSE } \\
\text { certification }\end{array}$ \\
\hline 11 & $\begin{array}{l}\text { If not, what are the factors that make you feel relatively safe staying } \\
\text { at the hotel? (Answer "-" if you chose yes in the previous question) }\end{array}$ & $\begin{array}{l}\text { Most respondents will feel safe if the hotel } \\
\text { provides tangible evidence of the cleanliness } \\
\text { and safety of the hotel, not just a certificate. } \\
\text { Some also rate safe hotels based on ratings } \\
\text { and reviews from customers. }\end{array}$ \\
\hline 12 & $\begin{array}{l}\text { In your opinion, what things need to be improved by hoteliers in the } \\
\text { city of Bandung in order to increase visits? E.g., improve the } \\
\text { cleanliness, improve the innovation, use current technology, etc. }\end{array}$ & $\begin{array}{l}\text { Promotion, improving cleanliness, } \\
\text { implementing strict health protocol, and } \\
\text { price is the most inputs for hotels. }\end{array}$ \\
\hline
\end{tabular}

Besides, the researcher also needs secondary data to support the observation. Secondary data are collected from the customer feedback through travel applications and personal blogs. The secondary data are also used to find competitors' data like price, facilities, and customer opinion. The review and rating of the Atlantic City Hotel will be shown in the table below. 


\section{International Journal of Current Science Research and Review}

ISSN: 2581-8341

Volume 05 Issue 02 February 2022

DOI: 10.47191/ijesrr/V5-i2-04, Impact Factor: 5.825

IJCSRR@ 2022

Table 2. Atlantic City Hotel Review

\begin{tabular}{|c|c|c|c|c|c|c|}
\hline \multirow{2}{*}{ No } & \multirow{2}{*}{ Websites } & \multirow{2}{*}{ Total Review } & \multirow{2}{*}{ Total Score } & \multicolumn{3}{|l|}{ Criteria } \\
\hline & & & & Location & Cleanliness & Service \\
\hline 1. & Pegipegi & 178 & $\begin{array}{l}8.5 \\
\text { Out of } 10\end{array}$ & 9.0 & 8.4 & 8.4 \\
\hline 2. & Tiket.com & 407 & $\begin{array}{l}4.1 \\
\text { Out of } 5\end{array}$ & 4.3 & 4.0 & 4.1 \\
\hline 3. & Traveloka & 8,857 & $\begin{array}{l}8.5 \\
\text { Out of } 10\end{array}$ & 9.0 & 9.0 & 9.0 \\
\hline 4. & TripAdvisor & 90 & $\begin{array}{l}4.0 \\
\text { Out of } 5\end{array}$ & 4.5 & 4.5 & 4.0 \\
\hline 5. & Agoda & 663 & $\begin{array}{l}7.8 \\
\text { Out of } 10\end{array}$ & 8.5 & 7.6 & 7.8 \\
\hline
\end{tabular}

Based on Table 2, Atlantic City Hotel gets an excellent review. The location of the Atlantic City Hotel is indeed a significant advantage. When viewed from the reviews and comments section, the bathroom condition is a complaint that many customers have submitted. The condition of the bathroom is rusty and smells, so it seems poorly maintained. In addition, some complaints about the dim bathroom lights and the condition of the shower, which seems to be rarely cleaned, so it is less effective for draining water. SWOT (Strengths, Weaknesses, Opportunities, and Threats) Analysis is one of the tools to assess a company to define a new strategy. In this research, we combine the internal analysis to define the strengths and weaknesses of Atlantic City Hotel. In contrast, the external analysis is used to build the opportunities and threats of Atlantic City Hotel. Table 3 explains the SWOT of the Atlantic City Hotel.

Table 3. SWOT Analysis of Atlantic City Hotel

\begin{tabular}{|c|c|}
\hline Strengths & Weaknesses \\
\hline $\begin{array}{l}\text { a) Strategic location, } \\
\text { b) The facilities are relatively modern, } \\
\text { c) Competitive price, and } \\
\text { d) Cleanliness, Health, Safety, Environment } \\
\text { Sustainability (CHSE) Certification. }\end{array}$ & $\begin{array}{l}\text { a) The hotel has limited facilities and } \\
\text { b) Cleanliness issue. }\end{array}$ \\
\hline Opportunities & Threats \\
\hline $\begin{array}{l}\text { a) The development of entertainment centers or } \\
\text { recreational areas, } \\
\text { b) West Java tourism tagline "Travelling in West Java } \\
\text { Only." } \\
\text { c) The improvement of technology, and } \\
\text { d) The economy starts to grow, and the hope in society } \\
\text { is rising. }\end{array}$ & $\begin{array}{l}\text { a) The pandemic is not over yet and } \\
\text { b) Government restrictions }\end{array}$ \\
\hline
\end{tabular}

After the SWOT of Atlantic City Hotel is formed, the TOWS matrix is used as the extension of SWOT analysis that combines the external and internal analysis. The matrix involved the managers of Atlantic City Hotel in analyzing their hotel's circumstances and developing strategies and activities for the successful and productive fulfillment of its organizational goals and mission. The following table shows the matrix. 


\section{International Journal of Current Science Research and Review}

ISSN: 2581-8341

Volume 05 Issue 02 February 2022

DOI: 10.47191/ijesrr/V5-i2-04, Impact Factor: 5.825

IJCSRR@ 2022

www.ijesrr.org

Table 4. TOWS Matrix Analysis Atlantic City Hotel

\begin{tabular}{|c|c|}
\hline $\begin{array}{l}\text { Strength-Opportunity Strategies: } \\
\text { 1. Add a new tourist recreational area in Bandung as a new } \\
\text { selling point to customers (S.1. \& O.1.) } \\
\text { 2. Updating facilities such as adding technology that can } \\
\text { prevent the transmission of covid-19 (S.2., S.4., \& O.2.) } \\
\text { 3. Maintaining competitive prices to welcome economic } \\
\text { improvement (S.3. \& O.3.) } \\
\text { 4. Promoting the hotel strengths through the digital channel to } \\
\text { the urban population (S.1., S.2., S.3., S.4., O.2., \& O.3.) }\end{array}$ & $\begin{array}{l}\text { Weakness-Opportunity Strategy: } \\
\text { 1. Provide the new recreational area in Bandung as the } \\
\text { promoting program (W.1. \& O.1.) } \\
\text { 2. Bringing entertainment things with new technology (W.1. } \\
\text { \& O.1.) } \\
\text { 3. Add new cleaning technology (W.2. \& O.2.) }\end{array}$ \\
\hline $\begin{array}{l}\text { Strength-Threat Strategies: } \\
\text { 1. Improve and utilize existing facilities so guests can reduce } \\
\text { mobilization (S.2., T.1., \& T.2.) } \\
\text { 2. Reducing the intensity of facilities maintenance since the } \\
\text { facilities are pretty new (S.2. \& T.2.) } \\
\text { 3. Evaluating the price to keep the competitive price (S.3., T.1., } \\
\text { \& T.2.) } \\
\text { 4. Stimulating aspects of environmental sustainability to } \\
\text { overcome environmental damage around Bandung (S.4. \& } \\
\text { T.3.) }\end{array}$ & $\begin{array}{l}\text { Weakness-Threat Strategy: } \\
\text { 1. Promote outdoor recreation (W.1. \& T.1.) } \\
\text { 2. Using limited hotel facilities effectively reduces company } \\
\text { expenses (W.1. \& T.2.) }\end{array}$ \\
\hline
\end{tabular}

The following strategy will be derived using Porter's Generic Strategy. Currently, Atlantic City Hotel is implementing the cost leadership strategy. The general manager states that the Atlantic City Hotel's strength is its competitive price. The hotel always tried to provide the best price for the customers. Price is also a determining factor for demand amid very tight market competition, as experienced by Atlantic City Hotels. In one area there are several hotels with the same star level and prices are not much different. However, this research suggests that Atlantic City Hotel can maintain the cost-leadership implemented and add uniqueness as the differentiation strategy. Hotels can raise cleanliness, health, security, and environmental sustainability issues as a unique value for hotels considering that Covid-19 cannot be predicted when it can be conquered. Facilities and services are the main milestones in presenting uniqueness to customers. As a unique value, hotels can increase the use of technology in their services. Guests can selfcheck-in and choose their breakfast menu using an online application/form.

Another strategy that be used in the research is Diamond Strategy. There are five elements in diamond strategy that the company, such as: can implement

- $\quad$ Arenas (where are we going to be activated?): The Atlantic City Hotel can provide rooms for three kinds of guest: staycation guests (someone who travel to the same city for a short time), business guests, and tourist guests.

- Vehicles (how we will get there?): The Atlantic City Hotel has been doing partnerships with travel e-commerce and the travel agent and has been growing organically. However, the hotel can do the partnership and work closely with the ministry of tourism or tourism schools to train their employees in dealing with changing service providers during the pandemic. The hotel can also develop the technology by investing in research and development.

- Differentiation (how will we win in the marketplace?): Atlantic City Hotel can differ in the brand image, price, styling, and quality. Hotels can build a hotel image that maintains cleanliness and security for the guests' comfort during this pandemic. The enforcement of health protocols evidences this image in the room and when serving food.

- $\quad$ Staging (what will be our speed and sequence of moves?): First, hotels need to invest in the development of technology and facilities. Second, cooperation with third parties that can improve employee capabilities needs to be carried out. Finally, 


\section{International Journal of Current Science Research and Review}

ISSN: 2581-8341

Volume 05 Issue 02 February 2022

DOI: 10.47191/ijesrr/V5-i2-04, Impact Factor: 5.825

IJCSRR@ 2022

www.ijcsrr.org

companies need also to activate all channels that can be used as marketing media. Social media and digital content can be used as examples of media to attract millennial guests.

- $\quad$ Economic logic (how will we obtain our returns?): Atlantic City Hotel earns the profit by selling the rooms, meeting rooms, restaurant, laundry services, catering box, and delivery fee.

The final strategy is adjusting the business model canvas of Atlantic City Hotel. Nine elements support company to align their actions, such as:

- Customer Segments: Hotel customer segments are business guests, staycation guests (guests both family and individual who spent a vacation in one's home city in a short time), and tourists.

- Value Propositions: Strategic locations and convenience are two value propositions in Atlantic City Hotel that can be maintained. The hotel can be added their focused-on new values like cleanliness, health, safety, and environmental sustainability.

- Channels: The hotel has been using good ways to distribute its service, such as its website, travel application (Traveloka, Tiket.com, Agoda, and Pegi-Pegi), some travel agents, and direct selling to the customer (e.g., local government for MICE activities).

- Customer Relationship: The hotel can add new ways to build customer relationships. Hotels can use a touching greeting card as an indirect form of welcoming and warmth and send a promotional e-mail in a birthday greeting or just a regular promotional e-mail.

- $\quad$ Revenue Streams: The most considerable revenue still comes from the sale of rooms, and other sources come from sales of meeting room packages for various purposes, sales of food and beverages, and sales of services for Spa and laundry.

- $\quad$ Essential Resources: Atlantic City Hotel's key resources consist of its high quality of human resources, financial assets like proper planning for running the operation, and assets such as building and other physical assets.

- Key Activities: The hotel's key activities remain the same, including managing the booking, servicing the guest, cleaning, and maintaining the assets, marketing their business, purchasing for the business operation, improving the quality of human resources, maintaining the database of customer and build the customer loyalty.

- Key Partners: Hotel existing partners such: suppliers to provide the business operational goods, travel agents, and travel ecommerce to help the hotel to market its rooms and services to the customers, and local government as the executor of the task force that grants activity permits during the pandemic.

- Cost Structures: The most valuable cost incurred for the hotel are maintenance of the building, labor cost, marketing cost, purchasing cost, third-party commission.

\section{CONCLUSION}

This pandemic has destroyed all tourism industries both in Indonesia and in the world. This sector is the first to be affected and the last to improve, including the hotel industry. At the beginning of the pandemic, around 500 hotels in West Java were closed. However, Atlantic City Hotel can still operate without experiencing closure, although with some restrictions as a form of adjustment.

The room occupancy rate decreased because of government restrictions which also affected hotel revenues. The occupancy rate was down 55\% to 15\%, while the profit declined $97.5 \%$ from IDR 6 billion to IDR 150 million. MICE events are significantly reduced due to crowd restrictions and hotel targeted customers from e-commerce and the mystery market (no exact market). In addition, the hotel only sold the room without any breakfast and the hotel's selling cost around IDR 250,000 for one night during the pandemic. These limitations faced by the hotel should be responded to prevent more extensive losses carefully. The hotel reduced employees' daily work hours and employed only $50 \%$ of employees with the contract. Then, Atlantic City Hotel asked for relief from TV cable and internet providers. They also limit the use of Wi-Fi by combining the internet lines used by a reception and guest rooms. Other efficient uses of electricity are also carried out, such as using only one lift, turning off lights on floors that are not operating, and temporarily stopping regular elevator maintenance.

Although the activities implemented for the sustainability of the hotel run well, this cannot last long. At the very least, hotels must adjust their strategy and financial policies to survive this pandemic. The hotel must innovate several service and cleanliness sectors. These innovations can generally be carried out by improving technology. One of the innovations is to present self-check-in, thermal cameras, and barcodes for the breakfast menu. Atlantic City Hotel should also improve the technology, maximize, and maintain 


\section{International Journal of Current Science Research and Review}

ISSN: 2581-8341

Volume 05 Issue 02 February 2022

DOI: 10.47191/ijcsrr/V5-i2-04, Impact Factor: 5.825

IJCSRR@ 2022

www.ijcsrr.org

outdoor recreation areas, and review the financial policy. Besides, the hotel could apply the cost-leadership and differentiation strategy simultaneously. So, Atlantic City Hotel can maintain the cost-leadership that has been implemented and add uniqueness as the differentiation strategy. Hotels can raise cleanliness, health, security, and environmental sustainability issues as a unique value for hotels considering that Covid-19 cannot be predicted when it can be conquered.

\section{REFERENCES}

1. Bordean, O. N., Borza, A. I., Nistor, R. L., \& Mitra, C. S. (2010). The Use of Michael Porter's Generic Strategies in the Romanian Hotel Industry. International Journal of Trade, Economics and Finance, 1(2), 173-178. https://doi.org/10.7763/ijtef.2010.v1.31

2. Hambrick, D. C., \& Fredrickson, J. W. (2001). Are you sure you have a strategy? Academy of Management Perspectives, 15(4), 48-59. https://doi.org/10.5465/ame.2001.5897655

3. Mansfield, T. (2019, July 26). Alex Osterwalder's Business Model Canvas template: why use it and how. The Interaction Consortium. Retrieved October 28, 2021, from https://interaction.net.au/articles/business-model-canvastemplate/\#:\%7E:text=The\%20Business\%20Model\%20Canvas\%20is,part\%20of\%20his\%20PhD\%20research.

4. Martina Minarik. (2007, March). Cost Leadership \& Differentiation - An investigation of the fundamental trade-off between Porter's cost leadership and differentiation strategies. Stockholm School of Economics. http://arc.hhs.se/download.aspx?MediumId=315

5. Online, F. E. (2021, January 10). Combining SWOT analysis with TOWS strategies can help small and large businesses scale up. The Financial Express. Retrieved October 28, 2021, from https://www.financialexpress.com/opinion/combiningswot-analysis-with-tows-strategies-can-help-small-and-large-businesses-scale-up/2168246/

Cite this Article: Gilang Permana Rachman, Anh-Dung Do (2022). Business Strategy for Atlantic City Hotel Facing Covid-19 Pandemic. International Journal of Current Science Research and Review, 5(2), 333-340 